\title{
What Made You Who You Are? Universal Life Lessons on Proversified Leadership, a Phenomenology
}

\author{
Nida H. Garcia, EdD ${ }^{1,2,3}$ and Alexander S. Acosta, PhD 1, 2, 3, 4 \\ ${ }^{1}$ Technological University of the Philippines, Manila, Philippines \\ ${ }^{2}$ Philippine School Doha, Doha, State of Qatar \\ ${ }^{3}$ Association of Philippine Schools Overseas \\ ${ }^{4}$ Philippine Christian University, Manila, Philippines
}

\begin{abstract}
Within the context of school leadership as a powerful process of impacting the life of people and making great things happen, Philippine Schools Overseas (PSO's) administrators have demonstrated significant life lessons they could pass on to leaders not only of the academe but also to aspiring and seasoned leaders of any kind of organizations here and beyond. Using an in depth semi-structured interview; this qualitative phenomenological research has uncovered the consequential evidence that plays around PSO Administrators' concept of proversified leadership. The universal life lessons as revealed in this study cover three major aspects of human existence namely: corporeal; considered as the lessons related to the earthly existence of man, relational; those relevant to human associations, and existential; the lessons about the meaning of life. Needless to say, these life lessons are meant to teach, to inspire, and drive school leaders and affiliate officials to action; to create the change they want to see in their respective schools and the world in general.
\end{abstract}

Keywords: Proversified Leadership, Corporeal Life Lessons, Relational Life Lessons, Existential Life Lessons, Phenomenology

\section{Introduction}

Leadership is a powerful ground for people to inspire, influence, and impact the life of others. According to Stathakis (2019), to inspire is to share one's vision, to influence is to make people follow and to impact is to get results. Leaders, through their special skills and abilities empower those around them to be better and to do their best. The more leaders engage in the practice of exemplary leadership, the more likely it is for them to have a positive influence in the life of others (Kouzes \& Posner, 2011) and the greater is their opportunity to contribute to the overall success of the organization. Inspiration, influence, and impact; however, areachieved not only through engagement. They are likewise realized through significant life lessons, leaders themselves learn from their very own experiences proving that life as cited by Adamsen (2018) is a continuous learning experience; people all throughout their lives keep rising and falling, picking up important lessons along the way. These valuable lessons, when pass on to others, will undoubtedly help build decision makers, global leaders, and world changers.

Truly, great lessons are learned from life. Taking into account the experience of school leaders, years spent living with and leading people of diverse nature uncovered important truths that reverberate some significant lessons about life and leadership which simply do not change over time. This research is therefore conducted to uncover the enduring leadership truths enfolded in the consequential evidence that plays around Philippine Schools Overseas administrators' concept of proversified leadership. Proversified leadership as inspired by Graham's (1997) concept on proversity; the energy that comes from seeing beyond the differences between and among people of different background and recognizing the common characteristics and interests they share, is a new leadership genre that serves as facility through which these school administrators manage diversity in their unique work environment (Garcia \& Acosta, 2019). Through this phenomenological study the researchers explore the rich experiences of a select group of school principals and coordinators as they lead a highly diversified learning environment. Their unique leadership story surely offers valuable perspective others can benefit from. In essence, this paper conforms to the reality that life is full of important lessons. Some of these valuable lessons are best learned through experience.

When delivered from the heart and told by trusted sources, life lessons can inspire leaders and non-leaders alike to dream bigger, perform better, achieve more and eventually, make this world a better place.

\section{Method}

\subsection{Research Design}

Qualitative in orientation and phenomenological in design.; this study endeavors to understand the essence of people's lived experiences. Phenomenology as explained by Neuber et al. (2019) is a form of qualitative research 
that focuses on the study of an individual's lived experiences within the world. According to Teherani et al. (2015) It Can be defined as an approach to research that seeks to describe the essence of a phenomenon by exploring it from the perspective of those who have experienced it, the goal of which is to describe the meaning of this experience - both in terms of what was experienced and how it was experienced. In order to understand the unique experience of Philippine Schools Overseas administrators, as a consequential evidence that plays around their very own concept of proversified leadership, phenomenological design is thus utilized.

\subsection{Locus and Participants}

Eleven school administrators representing Philippine Schools Overseas in the Middle East and North Africa (MENA) participated in this research. They have served as school principals or coordinators for more than five years in any of the Philippine Schools in the State of Qatar, United Arab Emirates, Sultanate of Oman, Kingdom of Bahrain, Kingdom of Saudi Arabia, and the State of Libya. Two of the respondents have worked as such for more than twenty years. Of the six principals, two were Doctors of Education and the rest were master's degree holders. Similarly, the five coordinators were MA graduates and one was a bachelor's degree holder. Small samples selected purposively were used in this study to provide richly textured information, relevant to the phenomenon under investigation and to support the depth of analysis called for by the research (Vasileiou et al., 2018).

\subsection{Data Collection and Ethical Consideration}

A two-part instrument was used to gather the data needed in this study. The first part was the robotfoto (Kelchtermans \& Ballet, 2002) which served as the demographic sketch of the respondents to include data such as gender, civil status, work experience, and years of service. The second part was a twenty-five-item semi structured interview consisting of open-ended questions that probe into the dynamics of the leadership practices of the Philippine Schools Overseas. The researcher sought permit to conduct interviews and a letter of intent was sent to target participants. With the permission and signed consent of the respondent, a one-hour audio and video taped interview was conducted. Respondents were assured that their response will be treated with utmost confidentiality.

\subsection{Data Analysis}

To increase the understanding of the phenomenon and transform data into meaningful findings, the researcher conducted an in-depth analysis following Colaizzi's process for phenomenological data analysis (Sanders, 2003; Speziale\& Carpenter, 2007). Transcripts were read and re-read in order to obtain a general sense of the interviewees' idea or opinion. Significant statements that pertain to the phenomenon under study were extracted and meaning units were identified. The researcher transformed each meaning unit from the language of the interviewees (emic) to the language of the researcher (etic). The formulated meanings were then sorted into categories, clusters of themes, and themes via a dendogram. Themes emerged were subjected to triangulation and member checking procedures in order to ensure validity and data trustworthiness (McWilliam et al. 2009). Findings were finally presented in a visual form through the creation of a simulacrum.

\section{Findings}

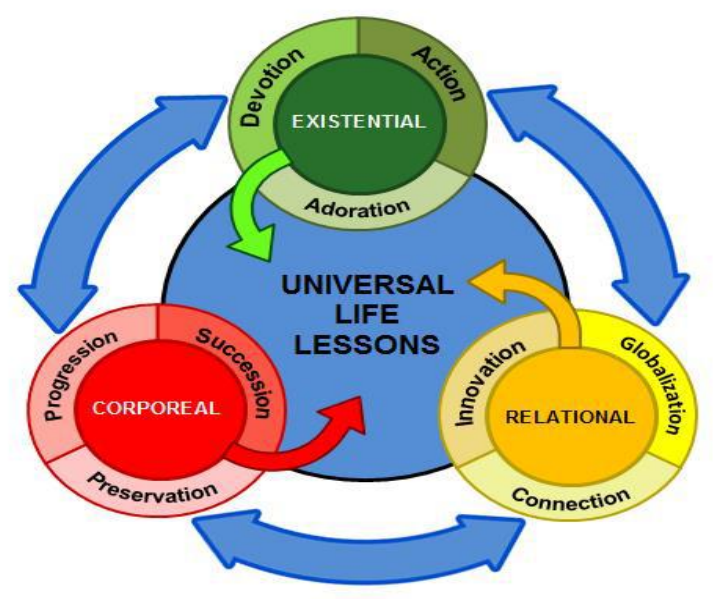

Figure 1: Universal Life Lessons

This figure displays three interrelated teachings revealed from the musings, verbalizations, and articulations of the respondents. On one hand, preservation, progression, and succession illustrate universal lessons on corporeal aspect of human life. Relational universal life lessons, on the other hand, are demonstrated through connection, innovation, and globalization while existential universal life lessons can be personally attained through adoration, devotion, and action. 
Capturing the lived experiences of a select group of school administrators of Philippine Schools Overseas, this phenomenological study has given birth to simple but important truths that could guide leaders all over the world in their everyday action. These life lessons encompass the corporeal or physical nature of man, the relational aspect of his being and the meaning of his existence primarily rooted from all areas of human life's experiences such us dealing with himself or herself, dealing with others, and guiding them to be leaders-in-the-making.

\subsection{Corporeal Life Lessons}

Leaders' worth is a reflection of how they value themselves. Subordinates tend to perceive leaders in the manner they perceive themselves. Leaders, therefore, must have a positive self-outlook. They must see themselves as good persons who deserve nothing but good; thus, building self-worth emanates from trusting and appreciating oneself before trusting others.

Administrators of Philippine Schools Overseas observe the principles of preservation, progression, and succession in their continuous quest for building self-esteem, keeping the dignity of their profession, and achieving what is best for themselves and for their respective schools. When asked what they want to achieve for themselves in the future, administrators vehemently expressed:

"I hope to achieve the PAASCU accreditation and put additional structures for the school to continue to grow and develop before retirement." $P 5$

"To train coordinators or assistant principals to fully qualify them for a principal's post before going back to the Philippines to be with my family." PO

Truly, the aspect of one's personality, especially a leader, plays a vital role in achieving and maintaining the leadership capability and the management skills of school administrators. Consequently, the PSO administrators' love for their school is inexhaustible; beyond love for oneself at times. Hence, they want to preserve whatever the school is good at, they dream for its progress, and they want to turn the school over to individuals who are ready to assume leadership responsibility and have built or developed their self-worth and self-respect for themselves.

\subsection{Relational Life Lessons}

Leadership connotes relationship. It brings people together, binds a common purpose, and channels people's action toward the realization of the shared vision. Relational lesson talks about life of a leader when being with his or her colleagues or subordinates. It is spelled outin the PSO culture as connection, innovation, and globalization. As such, a leader needs to be an embodiment of virtues who is likely to promote good working relationship and demonstrates the value of preserving human relationship as well. When asked what advice she can give to future PSO leaders, one administrator clearly stressed: "Be a value-based leader; be more patient, understanding, communicative, consultative, and diplomatic. Relate well with people but know the limitations." ${ }^{C l}$ This means leading, working, and living in conformity to the values that unite people.

Building positive relationship is often difficult, but influencing and sustaining employees to come up with creative ideas in a dynamic organization like PSO, is definitely more challenging. One coordinator averred:

"You have to come up always with new ideas because everything is very dynamic and active so if you are not resilient you will not strive here." $\mathrm{C2}$

This speaks of globalizing competitiveness of PSO's as one principal envisions a globally competitive school, conformed to by one who also believes that reaching the global strata is a significant life lesson. A leader must exhibit "good governance, quality product and good name for the Philippines." $P 2$

Logically, placing a leader in a more complex world, especially in the global arena, he or she needs a dynamic and empowering spirit to ensure that his or her ideas are truly acceptable by the people who he or she leads and to provide productive and meaningful result in the global scale; thus, relational is a universal life's lesson that embodies leader's kinship with what is going on around him or her upon which wisdom becomes the integral part of his or her leadership journey.

Unless a leader establishes connection with his or her peers, colleagues and subordinates, he or she will not be able to relate effectively with people. Connection, along with the leaders' drive for innovation and globalization are powerful lesson avenues that may direct leaders' actions and decisions.

\subsection{Existential Life Lessons}

It is undoubtedly a natural human tendency to search for the meaning or purpose of life. This human inclination to find answers to the significance of living gives man reasons to do the things that he must, to engage fully in an activity, to do his work well, to perform his role actively, to unceasingly inspire people, to dream big, and to constantly strive for excellence. Learning through and from their experiences in leading people, PSO administrators, have beautiful sharing on the significant lessons they learned which they want to pass on to other leaders. 
These life lessons can be described as existential expressed by PSO principals and coordinators through adoration, devotion, and action. One administrator narrated: "Whatever God has given me, I just want to give it back to Him for His glory!" ${ }^{P 2}$ This revealed PSO administrators main driving force in carrying out their responsibility, that is, to be able to glorify God. This faith instills in their heart the love and devotion for work which push them to cling to God at all times. One principal strongly recommended:

"Never lose your faith in God because if you have that faith everything becomes smooth. You will do your job according to or based on His commandments. You will be honest. You will be straight. You will have that commitment because you will always think that what you do is for the glory of God."P4

Finally, adoration and devotion move PSO administrators to action; to do their very best at all times. As one respondent said, "Give the world your best and the best will come back to you. "PS

Undeniably, leaders' actions and decisions are driven by their faith, their strong belief in the existence of God, their connection to the transcendent which moves them to the right direction, inspires them to serve others, motivates them to work wholeheartedly and enables them to uphold life and live according to its purpose as spiritually grounded leaders.

\section{Discussion}

\subsection{Corporeal Life Lessons}

Leaders just like any human beings have needs to satisfy. These sets of needs according to Maslow are rooted in human biology and can be categorized either as the deficiency needs or the basic physical requirements including the need for food, water, sleep, and warmth; the meta needs or growth needs which stem from an individual's desire to grow as a person, and the need for self-transcendence; a step beyond self-actualization realized when the person isfreed from the practice of categorizing, pre-judging and stereotyping the world and other people in it and unite with and serve that which is beyond the individual self: the unity of all being (Cherry, 2015; Fraser, 2014; Venter 2012; Venter \& Venter, 2010; Ryckman, 2008; and Koltko-Rivera, 2006). As a humanist, Maslow believed that people have an inborn desire to accomplish things, have their efforts recognized, grow personally, fulfill their potentials, and to be all they can possibly be (Cherry, 2015). PSO administrators' corporeal life lessons are grounded from these realities and could be perceived either as preservation, progression, and succession.

Interestingly, there are certain things PSO principals and coordinators would like to safeguard and preserve as leaders with positive self-concept. These include among others respect for oneself and love for one's profession and the school. PSO administrators through years of solid experience as leaders have proven that self-respect is essential to living a happy and authentic life. For them, self-respect simply means believing in what one can do, trusting one's giftedness, showing the natural self, growing where one is planted and being the person, one is intended to become. Moscovici (2014) described it as a form of self-love that solidifies people's identities and protects them from dangerous pathologicals, thus, gives individuals definition and boundaries. Fundamental for a great life, all leaders must try to develop self-respect by cultivating self-confidence to overcome insecurities and be able to deal with whatever life throws (Pettinger, 2008).

Similarly, PSO administrators' healthy self-perception is manifested in their passion for work and love for their profession which drive them not only to pursue higher education and inspire their subordinates to do the same but also to embark on school accreditation. Accreditation is an independent process whereby the quality of an institution is assessed and assured by accrediting bodies to develop a quality conscious system of education where excellence, relevance to market needs, and participation by all stake holders are warrantedensuring a teachinglearning environment as per accepted good practices and institutions which has the essential and desirable features of quality professional education signifying opportunities for future growth.

(Thiyagarajan \& Abdus Samad, 2014; Sinha \& Subramanian 2013, and Sahay \& Thakur, 2007). This is part and parcel of their continuous quest for progress and their inherent desire to be able to leave a legacy; a school, overseas Filipino children can proudly call their own. Relevant to the principle of progression, leadership succession is a prime concern among PSO administrators. As forward-thinkers, they want to ensure the safety and the continuous operation of the school by turning over the school leadership to somebody who shares the same advocacy and commitment. Hence, they train and develop people to qualify them to specific leadership positions. Ideally, careful succession planning grooms people internally (Bower, 2008; Boyle, 2009; Byrnes \& Crockett, 2009; Reingold, 2009), builds a leadership pipeline or talent pool to ensure leadership continuity, develops potential successors in ways that best fit their strengths, and identifies the best candidates for categories of positions (OPM, 2005). Rothwell as cited by Cardinal (2015) summarized the importance of succession planning by equating it to preservation of institutional memory, a deliberate and systematic effort designed to ensure the continued effective performance of an organization, division, department, or work group by making provision for the development and replacement of key people over time. 
Summarily, PSO's corporeal life lessons leave an impression that the foundation of great leadership is the leader himself; who he really is and how he sees himself; the totality of the 'being' he wishes to preserve and uphold which gives him the strength to be committed to something greater than himself, drives his effort to personal and organizational progress and inspires him to build a legacy that he can proudly pass on to his successors. This impressionleads to the leadership truths that credibility is the foundation of leadership, personal values drive commitment and focusing on the future sets leaders apart (Kouzes and Posner, 2010).

\subsection{Relational Life Lessons}

While positive self-image and personal growth are vital to leadership, findings in this study indicate significant lessons learned about the life of a leader as he builds relationship with people inside and outside his work environment. These lessons are spelled out in the PSO culture as connection, innovation, and globalization.

Effective leaders recognize the importance of building solid relationships, thus, they spend time focusing their efforts in key areas that build connections with the people they lead (Hopkin, 2011). Building connections as exemplified by PSO administrators means demonstrating values that preserve human relations and promote good working relationship. It is all about leading, working, and living in conformity to the values that unite people. Barrett (2010) termed it as internal cohesion in organizations, the most important value in building of which is trust; the value that bring people together and facilitates interactions, without which there can be no individual or collective bonding. Leaders, in order to earn trust, must have the character or the will to do what is right rather than what is easy; the commitment to stand through adversity and make sacrifices for the common good; the competency to stay fresh, relevant and capable yet humble and teachable; and the compassion to think beyond self and care sincerely for others (Horsager, 2012). These elements are demonstrated by PSO principals and coordinators as they exercise values-based leadership defined as leading by staying true to one's values and aligning them with organizational values expressed in the institution's mission, vision, strategy, performance measures, incentive programs and procedures (Slaughter, 2015; Mitchell , 2013; and Kraemer, 2011). There are, according to Kraemer (2011) four essential qualities of a values-based leader namely: self-reflection; a trait which empowers the leader to identify and evaluate his or her fundamental values; balance which allows him or her to view a situation from different perspectives; self-confidence which is essential for a leader to truly believe in himself or herself, and humility which enables him or her to respect others and value others' opinions. Consequently, PSO administrators practice democracy in leading their respective schools and exercise diplomacy in making organizational decisions. Values-based decision making; according to Barrett (2010) is a higher order decision making process based on values that unite people thus allowing the integration of differences in ethnicity by empowering team members to make decisions within the scope of their responsibilities and trusting them to make choices within the framework of the agreed values. This gives the notion that leaders and subordinates who share strong personal values aligned with those of the organization are likely to create a cohesive work environment where people work cooperatively together to advance a common good.

Undoubtedly, all kinds of organizations go through the process of growth and change. As highlighted by Horth\& Buchner (2014), leaders now a days need to be innovative in order to operate in challenging, unpredictable circumstances and must likewise be able to create a climate for innovation within organizations. Innovation is defined as a process of bringing new thinking and different actions to how leaders lead, manage, and go about their work which normally involves many people with various expertise for companies to accelerate the pace of change in today's global business environment (Horth \& Buchner, 2014; Baumgartner, 2013 and Barsh, Capozzi, \& Davidson, 2008). The power of innovation according to Horth \& Buchner (2014) can likewise be connected to multiple and varied concerns such as team effectiveness, decision making, managing multiple stakeholders, adapting to change, balancing regional and centralized functions, entering new markets, and product. The same applies to PSO setting.

Administrators of Philippine Schools Overseas speak of innovation in terms of modern facilities, new ideas, creative strategies, better services and flexible people to be able to relate well to the fast changing world and be at par with other schools and organizations when it comes to modernization.

There are multiple reasons why it is important for all sorts of organizations to master innovation (Balasubramanian, 2013). According to Potecea \& Cebuc (2010) innovation process is a necessary and very important step in companies' development as it offers companies important competitive advantage on domestic and foreign markets. Innovation as stressed by Shukla (2009) brings added value and widens the employment base, improves the quality of life and makes the world a better place for the younger generation. To highlight its significance Balasubramanian (2013) emphasized that only companies that constantly challenge what they do, challenge themselves to come up with new and different ways of doing things, and also constantly improve on things that they already do will survive in this new globally competitive environment.

Leaders therefore must take the lead towards successful innovation. They must become leaders of change, who provide an environment that encourages innovative thinking, who take calculated risks that will institute meaningful transformation through collaboration and quality practices (Wagner \& Compton, 2012). 
As achieving innovation success depends largely on decisions made by people, Potecea \& Cebuc (2010) encourage leaders to consider the existence of stimulation that cause people desire to innovate and improve creativity through better information, cooperation and training.

Lessons on innovation as exemplified by PSO administrators cannot be underestimated as they offer not only leaders of educational institutions but also of business and industries valuable insights on how to deal with change and survive in today's competitive world. Beckly as cited by Brooks (2013) justified that while innovation have slightly different meanings depending on the industry, its core is universal; it embodies the improvement of something that has come before and is the evolution of convenience, efficiency and effectiveness. It goes without saying that innovation is a call for all types of organizations; a challenge to the skill and expertise of leaders all over the world.

On the same impression, leaders must take note of the impact of globalization on leadership landscape and human relationship. As defined, globalization is the advance of human cooperation across national boundaries, the collaboration and integration among different people, countries, companies, and entities requiring them to think about their strategies, their portfolio of brands, the systems and processes that are needed to keep track of business across diverse geographies, and the effective development of supply chains. (Bains, 2012; Boudreaux, 2008; and Church, 2008). For PSO administrators, globalization is simply expressed in terms of global competence, global competitiveness, good governance, quality product, and good name for the home country.

On one hand, global competence is the capacity and disposition to understand and act on issues of global significance; the acquisition of in-depth knowledge and understanding of international issues, an appreciation of and ability to learn and work with people from diverse linguistic and cultural backgrounds, proficiency in a foreign language, and skills to function productively in an interdependent world community (Mansilla\& Jackson, 2011 and Van Roekel, 2010). On the other hand, global competitiveness according to Abdullah (2015) refers to the ability of a nation to create and maintain an environment that sustains more value creation for its enterprises and more prosperity for its people. Global competence and competitiveness in PSO culture can be best measured in the performance of the students, the quality of graduates, school standard, and the kind of service Philippine Schools Overseas continue to deliver as an avenue to bring pride and honor to the Philippines and the Filipinos all over the world.

PSO administrators' lessons on globalization pose a challenge to school leaders to promote global competence through partnership for 21st Century Skills and global learning, aligning teacher preparation programs with global perspectives, designing and supporting professional development programs with a global focus, expanding the teaching of foreign languages, and finding new ways to foster international exchanges as enumerated by Van Roekel, 2010. Similarly, these lessons serve as a reminder for leaders around the globe to create a truly global mindset that allows them to achieve strategic objectives by building diverse leadership teams at the top, immersing leaders in other cultures, developing strong relationship skills in executives, being clear on the values that matter, becoming more lean and agile, and accelerating the development of talent in different markets (Bains, 2012).

\subsection{Existential Life Lessons}

Indeed, leadership is a tough and challenging job. Leaders are constantly confronted with volumes of demands, critical projects, changing situations, difficult decisions, and unforeseen circumstances which challenge not only their abilities but also their person. Some challenges come in the form of people or problems that present obstacles to reaching a goal; others come from within the leaders themselves, or from the situation of simply being leaders (CTO, 2015). How they are able to recognize, face, and rise above these challenges for their own good, the good of others, and the glory of God exemplify existential life lessons demonstrated by PSO administrators through adoration, devotion, and action.

By and large, existentialism is a philosophy of life that is centered upon the analysis of human existence, the search and journey for true self and true personal meaning of life (Helaly, 2015). Most existentialists believe that there are certain questions everyone must deal with if they are to take human life seriously such as the place of God in human existence, the meaning of value, interpersonal relationship, the place of self-reflective conscious knowledge of one's self and the concept of death. Likewise, forerunners of existentialism describe many fundamental existential themes such as life without God is meaningless; we have everything to win and nothing to lose by faith in God and that an individual could, despite doubt, have faith that God exists and God is good (Pascal and Kierkegaard as cited by Leone, 2014; Flynn, 2009; and Skirbekk \& Gilje, 2001).

In the real sense, love accomplishes great things, but worship precedes it (Benhase, 2011). This implies that love is a powerful force that enables individuals to do boundless things; hence, love for work transformed into service drive most leaders to do things beyond what is expected of them. Service, however, as expounded by Benhase (2011) proceeds out of worship or adoration grounding individuals in something deeper and more eternal than simply the desire to be of greater service to humanity. This speaks of a reality revealed in this study as PSO administrators do their daily tasks, perform their responsibilities and offer their achievements to God as a form of adoration; an act of thanking and glorifying Him for His goodness in their life and the school as a whole. 
Similarly, these school leaders find meaning in working abroad, rise above personal and organizational challenges, and stretch beyond the boundaries of their very own understanding through strong faith and devotion; defined by Banks \& Powell (2000) as a belief of some kind in a supreme being, a cause or a goal, a method or even a technique. Basically, faith as expressed in the culture of PSO is both a belief in a worthy cause embodied in the vision -mission of the school and the trust in God which according to Pascal as cited by Pojman \& Rea (2008) allows people to accept transformation through His grace and that without a God, life would be meaningless, boring, and miserable.

Truly, the righteousness of God leads to the righteousness of men. Believing that there is somebody up there looking at them, school administrators try their very best to do the right things at all times. This is faithfulness, which according to Banks \& Powell (2000) is associated with certain kinds of behaviors or actions displayed by a person in his everyday dealings. Hence, PSO leaders' actions are marked by transparent integrity, servant attitude, and godly character (Cole, 2001) exhibited through patience, compassion, honesty, truthfulness, humility, and genuine concern for others. Through the faithful performance of their daily tasks, their day to day encounter with people, their constant struggles, and the choices and decisions they make, PSO leaders create their individual essence as they construct a meaningful PSO culture. This is tantamount to saying that as man exists he discovers the meaning and purpose of his life and being in the light of his personal experiences; the totality of the choices and decisions he makes, the practices he engages himself in, and all his actions and reactions as a member of his community; as directed by his guiding principles and beliefs in life. As expounded by Helaly (2015) man creates himself through choice and his being is nothing more than the sum total of his existence and experiences up to a certain point in his life thus, man never really forgets what he has previously learned because it all becomes part of his true essence and true self. Justification offered by Noonan (2006) highlighted that it is only in recognizing and accepting one's true self, who he really is, that one can work to actualize his full potential and live a meaningful life.

\section{Conclusion}

Each day is indeed an opportunity for every human person to live in accordance with his life purpose. Identifying that purpose; however, is a long cyclical process, each individual has to go through in order to live a happy and contented life. Connecting with and living one's purpose as described by Biali (2013) is a beautiful journey that typically unfolds in mysterious and surprising ways. Taking into account the experience of school administrators, the thickness and richness of their unique leadership culture led to the emergence of significant lessons about life and leadership which simply cannot be ignored. These enduring leadership truths cover three major aspects of human existence categorized as corporeal, relational, and existential.

PSO administrators' corporeal life lessons, on one hand, remind leaders of the value of the human persons as individuals with inherent and immeasurable worth which according to Paul as cited by Robinson (2011), far exceeds the dimensions of their earthly existence. As such, leaders must develop healthy self-perception, uphold self-respect, foster self- confidence, and work on self-empowerment as they preserve the dignity of their position and their profession, as they continue their quest for personal and organizational progress, and as they train the right people for succession. On the other hand, PSO's relational life lessons focus leaders' attention on the substantial value of human relationships in the workplace. Hence, effective leaders must lay the foundation in building a solid working relationship by establishing connection, preserving human relation and living in conformity with values that unite people. The demand of modern work environment; however, is greater as relationship and survival in the global environment calls for innovation and globalization.

Leaders and employees' capacity and disposition to understand and act on issues of global significance (Mansilla\& Jackson, 2011 and Van Roekel, 2010) and their ability to come up with effective new ideas are often the difference between the entire company's success and failure (Petryni, 2015).

The practice of living purposefully is essential to any genuine sense of control over one's existence (Branden as cited by Trish, 2014). This encompasses PSO's existential life lessons valuable to the modern - day leaders who inside the organization as described by Gentry, et al. (2014) lead and motivate a diversified group of people, work across organizational boundaries, improve efficiency, and achieve growth and externally, face a complex and globalized environment where they have to manage the requirements of government, keep up with competitors, and meet the expectations of other stakeholders. Leaders, therefore, must have a clear sense of purpose as it is purpose that gives leaders focus. They should be grounded in something deeper and more eternal as it is faith that gives them the courage to do the right things at all times. To live purposely is to think through faithfully, to keep one's commitment and to act for a cause greater than oneself.

Summarily, the consequential evidences that play around Philippine Schools Overseas Administrators' concept of proversified leadership which emerged in the form of meaningful universal life lessons serve not only as a valuable contribution in the leadership arena but also prove that phenomenology allows experiences of people to discover and disclose fascinating stories and meaning lessons that can bring out change, offer fresh ideas for change, adapt and value change at its best. 
Future school leaders and affiliate school officials should therefore consider the most important corporeal, relational, and existential life lessons, present PSO administrators would like to pass on, to serve the best interest of the school in all aspects of its existence and for them to live a genuinely purpose driven life as individual persons.

\section{References}

Abdullah, M. (2015). APO: Asian Productivity Organization. Retrieved December 28, 2015, from http://www.apotokyo.org/productivity/078_prod.htm

Adamsen, L. (2018, July 6). 10 important life lessons we are often taught too late. Ladders | Business News \& Career Advice. https://www.theladders.com/career-advice/10-important-life-lessons-we-are-often-taughttoo-late

Bains, G. (2012). What does globalization mean for your leadership culture? | YSC. Retrieved December 28, 2015, from http://www.ysc.com/our-thinking/article/what-does-globalisation-mean-for-your-leadership-culture

Balasubramanian, S. (2013). Insight into innovation: Why companies must innovate. Retrieved January 23, 2016, from www.kenan-flagler.unc.edu/news/2013/03/why-companies-must-innovate

Banks, R., \& Powell, K. (2000). Faith in leadership: How leaders live out their faith in their work-- and why it matters. San Francisco: Jossey-Bass.

Barrett, R. (2010). The New Leadership Paradigm A Leadership Development Textbook for the Twenty-first Century Leader. KY: Lexington, KY: Lulu.com, (02010.

Barsh, J., Capozzi, M., \& Davidson, J. (2008). Leadership and Innovation | McKinsey \& Company. Retrieved from http://www.mckinsey.com/insights/innovation/leadership_and_innovation.

Baumgartner, J. (2013). What is Innovative Leadership? | Innovation Management. Retrieved from http://www.innovationmanagement.se/imtool-articles/what-is-innovative-leadership/

Benhase, S. (2011). Faith and Leadership. Retrieved from https://www.faithandleadership.com/scott-benhase-dutyadoration

Biali, S. (2013). Helping You Find Your Life Purpose | Psychology Today. Retrieved January 15, 2016, from https://www.psychologytoday.com/blog/prescriptions-life/201311/helping-you-find-your-lifepurposeBoatright, J. R. (2003). Ethics and the Conduct of Business. Upper Saddle River, NJ: Prentice Hall.

Boudreaux, D. J. (2008). Globalization. Westport, CT: Greenwood Press.CIA. (2010). The World Factbook 2010. Washington, DC: Central Intelligence Agency. Retrieved from https://www.cia.gov/library/publications/the-world-factbook/

Bower, J. L. (2008, April 15). The leader within your company. BusinessWeek, downloaded from

http://www.businessweek.com/ on April 28, 2008.

Boyle, M. (2009, May 11). The art of succession. Business Week, pp. 31, 32.

Brooks, C. (2013). Innovation: Key to Successful Business. Retrieved from http://www.businessnewsdaily.com/5167-innovation.html

Byrnes, N., \& Crockett, R. O. (2009, June 8). An historic succession at Xerox. BusinessWeek, pp. 18-21.

Cardinal, R. (2015). 3 Important Phases of Succession Planning | Rosalind Cardinal [Web log post]. Retrieved from http://www.huffingtonpost.com/rosalind-cardinal/3-important-phases-of-successionplanning_b_7717482.html

Cherry, K. (2015). Maslow's Hierarchy of Needs. Retrieved from

http://psychology.about.com/od/theoriesofpersonality/a/hierarchyneeds.htm

Church, M. (2008). The Mentor: An Academic Advising Journal. Retrieved from

https://dus.psu.edu/mentor/old/articles/080820mc.htm

Cole, S. J. (2001). Lesson 51: Godly Leadership (Acts 20:17-21) | Bible.org. Retrieved from

https://bible.org/seriespage/lesson-51-godly-leadership-acts-2017-21

Community Tool Box - CTO. (2015). Chapter 13. Orienting Ideas in Leadership | Section 6. Recognizing the Challenges of Leadership | Main Section | Community Tool Box. Retrieved December 28, 2015, from http://ctb.ku.edu/en/table-of-contents/leadership/leadership-ideas/leadership-challenges/main

Flynn, T. R. (2009). Existentialism: A brief insight. New York, NY: Sterling Publishing Co., Inc.

Fraser, M. (2014). Welcome to PlanitDo! Unlock the Secrets to Your Wealth Creation Power. Bloomington, IN: WestBow Press.

Garcia, N. H., \& Acosta, A. S. (2019). Philippine Schools Overseas Capitalized Strength:Phenomenological Impact of Proversified Leadership. International Journal of Educational Policy Research and Review, 6(4), 100 111. https://doi.org/10.15739/IJEPRR.19.013

Gentry, W., Stawiski, S., Eckert, R., \& Zhao, S. (2014). The Challenges Leaders Face Around the World More Similar than Different. Retrieved from

http://insights.ccl.org/wp-content/uploads/2015/04/ChallengesLeadersFace.pdfGraham, L. (1997). Proversity: Getting past face value and finding the soul of people: a manager's journey. New York: Wiley.

Graham, L. (1997). Proversity: Getting Past Face Value and Finding the Soul of People, John Wiley and Sons Inc. 
Helaly, M. (2015). Existentialism as a Philosophy of Survival in the Modern World: An Interpretation. Retrieved December 29, 2015, from

http://www.academia.edu/8879261/Existentialism_as_a_Philosophy_of_Survival_in_the_Modern

Hopkin, M. (2011). Leadership is a relationship | Lead on Purpose. Retrieved from

http://leadonpurposeblog.com/2011/11/26/leadership-is-a-relationship/

Horsager, D. (2012). The trust edge: How top leaders gain faster results, deeper relationships, and a stronger bottom line. New York: Free Press.

Horth, D., \& Buchner, D. (2014). Innovation Leadership How to use innovation to lead effectively, work collaboratively, and drive results. Retrieved from Center for Creative Leadership website: http://insights.ccl.org/wp-content/uploads/2015/04/InnovationLeadership.pdf

Keltchtermans, G. \& Ballet, K. (2002). ,The micropolitics of teacher induction a narrative bibliographical study on teacher socialization. Teaching and Teacher Education, 18 (1), 105 - 120.

Koltko-Rivera, M.E. (2006) Rediscovering the Later Version of Maslow's Hierarchy of Needs: Self-Transcendence and Opportunities for Theory, Research, and Unification. Review of General Psychology, 10(4), 302-317.

Kouzes, J. M., \& Posner, B. Z. (2010). The truth about leadership: The no-fads, heart-of-the-matter facts you need to know. San Francisco, CA: Jossey-Bass.

Kouzes, J., \& Posner, B. (2011). Leadership Challenge: You Can't Do It Alone [Web log post]. Retrieved from http://leadershipchallenge.typepad.com/leadership_challenge/2011/04/you-cant-do-it-alone.html

Kraemer, Jr., H. M. (2011). From Values to Action: The Four Principles of Values-based Leadership. San Francisco: Jossey-Bass.

Leone, G. (2014). Kierkegaard's Existentialism The Theological Self and the Existential Self. Bloomington, IN: iUniverse LLC

Mansilla, V., \& Jackson, A. (2011). Educating for Global Competence: Preparing Our Youth to Engage the World. New York, NY: Asia Society.

McWilliam, C., Kothari, A. Ward-Griffin, C., Forbes, D. Leipert B. (2009). Evolving the theory and praxis of knowledge translation through social interaction : A social phenomenological study. Implementation Science, 4(2), 1-14.

Mitchell, E. J. (2013). How to Become a Values-Based Leader | SUCCESS. Retrieved from

http://www.success.com/article/how-to-become-a-values-based-leader

Moscovici, C. (2014). How Self-respect Can Save Your Life. Retrieved from

https://www.linkedin.com/pulse/20140513130527-77938080-cultivating-self-respect?forceNoSplash=true

Neubauer, B. E., Wiktop, C. T., \&Varpio, L. (2019). How phenomenology can help us learn from the experiences of others. Perspectives on Medical Education. https://link.springer.com/article/10.1007/s40037-019-0509-2

Noonan, C. (2006). The Search of The Self: An Existentialist Analysis of Nathaniel Hawthorne's "Young Goodman Brown," "The Minister's Black Veil," and "Wakefield" (An MA thesis, Southern Connecticut State University). Retrieved from http:ploto.stanfordencyclopedia.edu/entries/existentialism

Pettinger, T. (2008). How to Develop R-E-S-P-E-C-T for Yourself | PickTheBrain | Motivation and Self Improvement. Retrieved from http://www.pickthebrain.com/blog/self-respect/

Petryni, M. (2015). The Importance of Human Relations in the Workplace | Chron.com. Retrieved from http://smallbusiness.chron.com/importance-human-relations-workplace-23061.html

Pojman, L. P., \& Rea, M. (2008). Philosophy of Religion An Anthology. Belmont, CA: Thomson Learning Inc.

Potecea, V., \&Cebuc, G. (2010). THE IMPORTANCE OF INNOVATION IN INTERNATIONAL BUSINESS. The Annals of The "SStefancel Mare" University of Suceava. Fascicle of The Faculty of Economics and Public Administration, 10. Retrieved from http://www.seap.usv.ro/annals/ojs/index.php/annals/article/viewFile/332/342

Reingold, J. (2009, Dec. 7). The $\$ 79$ billion handoff. Fortune, pp. 81-86.

Robinson, D. (2011). Understanding the "Imago Dei": The thought of Barth, von Balthasar and Moltmann. Farnham, England: Asgate.

Ryckman, R. M., \&Ryckman, R. M. (2008). Study guide: Theories of personality, ninth edition. Belmont, CA: Wadsworth/Thomson Learning.

Sahay, B.S. \& Thakur, R. Rajiv (2007). Excellence through Accreditation in Indian B-Schools. Global Journal of Flexible Systems Management, vol.8, (4) P.9-16.

Sanders, C. (2003). Application of Colaizzi's method: Interpretation of an auditable decision trail by a novice researcher. Contemporary Nurse Journal, 14(3), 292-302.

Shukla, A. (2009). What is Innovation? Why Innovation is important? Retrieved December 27, 2015, from http://www.paggu.com/getting-into-roots/what-is-innovation-why-innovation-is-important/

Sinha, V., \& Subramanian, K. (2013). Accreditation in India: Path of Achieving Educational Excellence Vinita Sinha, Symbiosis Center for Management \& Human Resource. Business Education \& Accreditation, Volume 5(Number 2). Retrieved from ftp://ftp.repec.org/opt/ReDIF/RePEc/ibf/beaccr/bea-v5n22013/BEA-V5N2-2013-9.pdf 
Skirbekk, G., \& Gilje, N. (2001). A history of Western thought: From ancient Greece to the twentieth century. London: Routledge.

Slaughter, C. (2015). Staying True to Your Values is Easy Until... Retrieved December 26, 2015, from http://boldermoves.com/staying-true/

Speziale, H.J. and Carpenter, D.R. (2007). Qualitative Research in Nursing: Advancing the Humanistic Imperative, (4th ed.). Philadelphia. Lippincott, Williams and Wilkins.

Stathakis, C. (2019, January 11). Inspiration, Influence \& Impact. Stathakis | Premier Janitorial Services in Michigan. Retrieved March 15, 2020, from https://www.stathakis.com/blog/leadership/inspirationinfluence-impact

Teherani A, Martimianakis T, Stenfors-Hayes T, Wadhwa A, Varpio L. (2015) Choosing a qualitative research approach. J Grad Med Educ. 2015 Dec;7(4):669-70. doi: 10.4300/JGME-D-15-00414.1

Thiyagarajan, R., \&Abdus Samad, K. (2014). Accreditation of Indian B Schools for Assuring Quality and Excellence in Management Education. IRACST-International Journal of Research in Management \& Technology (IJRMT), 4(No.1). Retrieved from http://www.iracst.org/ijrmt/papers/vol4no12014/9vol4no1.pdf

Trish. (2014). Self-Esteem as a Spiritual Discipline. Retrieved January 15, 2016, from

http://www.gatheringspot.net/topic/personalspiritual-growth/self-esteem-spiritual-discipline

United States Office of Personnel Management - OPM. (2005). Succession Management - Training and Development Policy Retrieved from

https://www.opm.gov/policy-data-oversight/human-capital management/reference-materials/leadershipknowledge-management/successionplanning.pdf

Van Roekel, D. (2010). Global Competence Is a 21st Century Imperative. Retrieved from NEA Education Policy and Practice Department | Center for Great Public Schools | 1201 16th St., NW, Washington, D.C. 20036 website: http://www.nea.org/assets/docs/HE/PB28A_Global_Competence11.pdf

Vasileiou, K., Barnett, J., Thorpe, S., \& Young, T. (2018). Characterizing and justifying sample size sufficiency in interview-based studies: systematic analysis of qualitative health research over a 15-year period. BMC Medical Research Methodology. https://bmcmedresmethodol.biomedcentral.com/articles/10.1186/s12874018-0594-7

Venter, H. \& Venter, C. (2010). Globalization and the Psychology of the New World Citizen: How the New Global Citizen Compares to Maslowees Level of Self Transcendence. International Journal of Interdisciplinary Social Sciences, Volume 5, Issue 7, pp.29-36.

Venter, H. J. (2012). Maslow's Self-Transcendence: How It Can Enrich Organization Culture and Leadership. International Journal of Business, Humanities and Technology, Vol. 2 (No. 7), 64 - 71 . Retrieved from http://www.ijbhtnet.com/journals/Vol_2_No_7_December_2012/7.pdf

Wagner, T., \& Compton, R. A. (2012). Creating innovators: The making of young people who will change the world. New York: Scribner. 